\title{
REVIEW \\ Emodin: A Review of its Pharmacology, Toxicity and Pharmacokinetics
}

\author{
Xiaoxv Dong, ${ }^{1 \dagger}$ Jing Fu ${ }^{1 \dagger}{ }^{1 \dagger}$ Xingbin Yin, ${ }^{1}$ Sali Cao, ${ }^{1}$ Xuechun Li, ${ }^{1}$ Longfei Lin, ${ }^{1}$ Huyiligeq ${ }^{1,2}$ and \\ Jian $\mathrm{Ni}^{1 *}$ \\ ${ }^{1}$ School of Chinese Materia Medica, Beijing University of Chinese Medicine, Beijing 100102, PR China \\ ${ }^{2}$ Affiliated Hospital, Inner Mongolia University for Nationalities, Tongliao 028000, PR China
}

\begin{abstract}
Emodin is a natural anthraquinone derivative that occurs in many widely used Chinese medicinal herbs, such as Rheum palmatum, Polygonum cuspidatum and Polygonum multiflorum. Emodin has been used as a traditional Chinese medicine for over $\mathbf{2 0 0 0}$ years and is still present in various herbal preparations. Emerging evidence indicates that emodin possesses a wide spectrum of pharmacological properties, including anticancer, hepatoprotective, antiinflammatory, antioxidant and antimicrobial activities. However, emodin could also lead to hepatotoxicity, kidney toxicity and reproductive toxicity, particularly in high doses and with long-term use. Pharmacokinetic studies have demonstrated that emodin has poor oral bioavailability in rats because of its extensive glucuronidation. This review aims to comprehensively summarize the pharmacology, toxicity and pharmacokinetics of emodin reported to date with an emphasis on its biological properties and mechanisms of action. Copyright (C) 2016 John Wiley \& Sons, Ltd.
\end{abstract}

Keywords: emodin; pharmacology; toxicology; pharmacokinetics; mechanisms.

\section{INTRODUCTION}

Emodin (1,3,8-trihydroxy-6-methylanthraquinone) (Fig. 1) is a naturally occurring anthraquinone derivative and an active ingredient of Chinese herbs, including Rheum palmatum (Wang et al., 2011), Polygonum cuspidatum (Wang et al., 2012a), Polygonum multiflorum (Lee et al., 2011), Aloe vera (Naqvi et al., 2010) and Cassia obtusifolia (Yang et al., 2003). These herbs have been wildly used as traditional medicines in many countries, especially in eastern Asia. Currently, a number of researchers are focusing on the pharmacological effects of this compound. Previous reviews have summarized the anticancer and antiinflammatory properties of emodin (Shrimali et al., 2013; Wei et al., 2013). In the last 3 years, there have been many reports on the anti-tumour and antiinflammatory effects of emodin. Furthermore, emodin has been demonstrated to possess a wide spectrum of pharmacological effects, such as antiviral, antibacterial, anti-allergic, antiosteoporotic, anti-diabetic, immunosuppressive, neuroprotective and hepatoprotective activities. Moreover, the laxative property of emodin has been its primary mechanism of action for promoting weight loss (Matsuda et al., 2008).

These pharmacological properties suggest that emodin might be a valuable therapeutic option for the prophylaxis and treatment of various diseases, including constipation (Cirillo and Capasso, 2015), asthma, atopic

\footnotetext{
* Correspondence to: Jian Ni, School of Chinese Materia Medica, Beijing University of Chinese Medicine, Beijing 100102, PR China.

E-mail: njtcm@263.net

${ }^{\dagger}$ These authors contributed equally to this work.
}

dermatitis, osteoarthritis, diabetes and diabetic complications, atherosclerosis, Alzheimer's disease (AD), hepatic disease and several types of cancers, such as pancreatic cancer, breast cancer, hepatocellular carcinoma and lung carcinoma. However, an increasing number of recently published studies have reported adverse effects of emodin. The purpose of this review is to provide updated, comprehensive information on the pharmacology, toxicity and pharmacokinetics of emodin in the past few decades to explore the therapeutic potential of this compound and evaluate future research opportunities.

\section{PHARMACOLOGY}

\section{Anticancer activity}

Induction of apoptosis. Emodin significantly inhibited the cell growth of four bladder cancer cell lines by modulating epigenetic modifications in a dose-dependent and time-dependent manner (Cha et al., 2015). In another study, emodin $\left(\mathrm{IC}_{50}=3.70 \mu \mathrm{M}\right)$ was shown to modulate the expression of apoptosis-related genes to induce growth inhibition and apoptosis in A549 cells. Treatment with emodin helped to enhance apoptosis in A549 cells through up-regulation of the gene expression of Fas ligand (FASL) and disabled damage repair in A549 cells through down-regulation of the gene expression of C-MYC (Li et al., 2014b). Emodin could induce growth inhibition and apoptosis in MCF-7 cells through the modulation of the expression of apoptosis-related genes. The gene expression of FASL was up-regulated, 


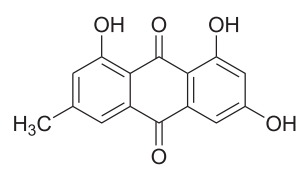

Figure 1. Chemical structure of emodin.

although the expression levels of MCL1, CCND1 and C-MYC were down-regulated (Li et al., 2013b).

Emodin effectively blocked the self-renewal activity of glioma stem cells by suppressing crucial stemness signalling pathways involving Notch-1, b-catenin and STAT3. Emodin induced proteosomal degradation of EGFR/EGFRvIII by interfering with its association with Hsp90, leading to partial induction of apoptosis and sensitization of glioma stem cells to ionizing radiation (Kim et al., 2014b). Wang et al. reported that emodin inhibited human cervical cancer HeLa cell proliferation by inducing apoptosis through the intrinsic mitochondrial and extrinsic death receptor pathways (Wang et al., 2013). Furthermore, emodin was also reported to potentiate TNF-related apoptosis-inducing ligand-induced apoptosis through the induction of death receptors and the down-regulation of cell survival proteins in hepatocellular carcinoma cells (Subramaniam et al., 2013).

Emodin significantly inhibited breast cancer cell proliferation by down-regulating $\operatorname{ER} \alpha$ protein levels (Huang et al., 2013). Xie et al. demonstrated that emodin-provoked oxidative stress induced apoptosis in human colon cancer HCT116 cells through a p53mitochondrial apoptotic pathway (Xie et al., 2014). A similar study showed that emodin could inhibit LOVO colorectal cancer cell growth via the regulation of the Bcl-2/Bax ratio and by its effect on the mitochondrial apoptosis pathway (Ma and Li, 2014a).

Wnt signalling is involved in the regulation of cell proliferation, differentiation and apoptosis. Emodin suppressed the Wnt signalling pathway in human colorectal cancer cells (SW480 and SW620) by downregulating T-cell factor/lymphoid enhancer factor transcriptional activity (Pooja and Karunagaran, 2014).

Anti-metastasis. Jia et al. demonstrated for the first time that emodin suppressed pulmonary metastasis of breast cancer by inhibiting macrophage recruitment and M2 polarization in the lungs by reducing STAT6 phosphorylation and CCAAT/enhancer-binding protein $\beta$ expression (Jia et al., 2014b). In another study, treatment with a combination of emodin $(10,20,40$ and $80 \mu \mathrm{M})$ and curcumin $(10 \mu \mathrm{M})$ inhibited the proliferation and invasion of breast cancer cells by increasing the expression of miR-34a (Guo et al., 2013b). It has been shown that emodin suppressed human breast cancer cell invasiveness in vitro and in vivo by antagonizing the P2X7Rs (Jelassi et al., 2013). Moreover, emodin dose dependently inhibited the migration and invasion of human breast cancer MDA-MB-231 cells by down-regulating the expression of MMP-2, MMP-9, uPA and UPAR and by decreasing the activity of p38 and extracellular regulated protein kinases (ERK) (Sun et al., 2015a).

Emodin treatment significantly suppressed metastasis to the lungs in an orthotopic hepatocellular carcinoma mice model and CXCR4 expression in tumour tissues (Manu et al., 2013). Way et al. demonstrated that emodin significantly inhibited TWIST1-induced cell migration and invasion by inhibiting the $\beta$-catenin and Akt pathways (Way et al., 2014).

Cell cycle arrest. An MTT assay, flow cytometry and electron microscopy were used to investigate the inhibitory effect of emodin on the human hepatoma cell line SMMC-7721. The results showed that the proliferation of SMMC-7721 cells was inhibited in a time-dependent and concentration-dependent manner, that cells in G2/M phase increased significantly and that the proportion of S-phase cells gradually declined (Zhang et al., 2015a).

Reversion of multidrug resistance. The overexpression of multidrug resistance (MDR) in tumour cells poses a serious obstacle to successful chemotherapy (Wesolowska, 2011). Our investigations demonstrate that emodin could sensitize tumour cells to chemotherapeutic agents via inhibiting pathways. Emodin/cisplatin co-treatment inhibited the growth of human ovarian carcinoma cells and gallbladder carcinoma cells in vivo. This mechanism might involve the downregulation of MRP1 expression (Ma et al., 2014b) and ABCG2 expression (Li et al., 2012b). In addition, the combination of emodin $(25 \mu \mathrm{M})$ and cisplatin $(3.0 \mu \mathrm{M})$ induced a relatively higher inhibitory effect on gastric cancer cells than that of individual treatment with emodin or cisplatin by inducing apoptosis and cell cycle arrest (Huang et al., 2015).

Chen et al. showed a synergistic growth-inhibitory effect of azidothymidine and emodin in K562/ADM cells. This effect might be mediated by $\mathrm{S}$ cell cycle arrest and decreased MDR1 mRNA/p-gp protein expression (Chen et al., 2013). Furthermore, the gene and protein expression levels of nuclear factor- $\kappa \mathrm{B}(\mathrm{NF}-\kappa \mathrm{B}), \mathrm{X}-$ linked inhibitor of apoptosis and survivin were suppressed in Bxpc-3/Gem cells treated with the combination of emodin and gemcitabine (Zhang et al., 2013).

Emodin inhibits cell growth in several types of cancer cells and regulates genes and proteins related to the control of cell apoptosis, cell invasion, metastasis and cell cycle arrest. Moreover, the synergistic enhancement of apoptosis is important in combination chemotherapeutic agents for cancer and has attracted attention as a promising avenue of treatment.

\section{Antiinflammatory activity}

Nuclear factor $-\kappa \mathrm{B}$ is involved in the transcription of various pro-inflammatory genes involved in disease progression. The antiinflammatory effect of emodin has been associated with the inhibition of the proinflammatory transcription factor NF- $\mathrm{BB}$. Gao et al. elucidated the antiinflammatory active components of Jiashitang scar removal ointment, including saffiomin, emodin, salvianolic acid, tanshinone and triterpenoid saponin derivatives. Among these active ingredients, emodin was predicted to exert NF- $\mathrm{BB}$-inhibiting effects through the mitogen-activated protein kinase (MAPK), PI3K/AKT and NIK-IKK pathways (Gao et al., 2014). In a collagen-induced arthritic mouse model, emodin exhibited its anti-arthritis effects through inhibition of the NF- $\kappa \mathrm{B}$ pathway and pro-inflammatory mediators (Hwang et al., 2013; Zhu et al., 2013). Moreover, emodin could improve the corneal structure and reduce corneal 
injure by suppressing the activation of NF- $\kappa \mathrm{B}$, c-JunNterminalkinase (JNK) and the expression of ICAM-1 (Kitano et al., 2007; Chen et al., 2009a, 2015a). In a severe acute pancreatitis (SAP) model group, emodin treatment significantly decreased the expression of Bip, inositol-requiring-1 $\alpha$ (IRE1 $\alpha)$, TNF receptorassociated factor 2 and ASK1 and inhibited phosphorylation of JNK and p38 MAPK by inhibiting ER stress transducers IRE1 $\alpha$ and its downstream molecules $(\mathrm{Wu}$ et al., 2013). Jia et al. found that emodin could halt the transition from simple steatosis to non-alcoholic steatohepatitis by suppressing Erk1/2 and p38 signalling in in vitro experiments (Jia et al., 2014a).

Reports also have shown that emodin has a protective role in rats with acute necrotizing pancreatitis by increasing the expression levels of mCD14 and inhibiting the serum expression levels of TNF- $\alpha$, IL- 6 and IL-1 $\beta$ (Ni et al., 2014; Yao et al., 2015). In lipopolysaccharide (LPS)-induced mouse mastitis, emodin could reduce LPS-induced mammary gland injuries and inflammatory cell infiltration, decrease myeloperoxidase (MPO) activation in the mammary gland, down-regulate the expression of TNF-a, IL- 6 and IL- $1 \beta$ and activate PPAR$\gamma$ in a dose-dependent manner (Yang et al., 2014b; Li et al., 2013a). A similar study showed that emodin considerably decreased the levels of TNF- $\alpha$, IL-6, MPO, malondialdehyde (MDA), CINC-1, MIP-2 and ICAM1. However, the levels of nitric oxide and inducible nitric oxide synthase were markedly increased (Ding et al., 2008).

Emodin could attenuate pulmonary oedema and inflammation, enhance alveolar epithelial barrier function and promote the expression of claudin-4, claudin-5 and occludin in lung tissues (Xia et al., 2010). Furthermore, emodin treatment effectively inhibited allergen-induced inflammation by reducing the Th2 immune response, suppressing MMP-9 expression and inducing HO-1 expression in a murine model of asthma (Wang et al., $2015 \mathrm{~b})$. LTs synthesized by the $5-\mathrm{LOX}$ reaction are believed to play an important role in atopic dermatitis, and Jin et al. demonstrated that emodin possessed a 5-LOX inhibitory action (Jin et al., 2011).

The study results reflect that emodin is capable of inhibiting the activation of NF- $\mathrm{B}$, JNK, p38 MAPK, Erk1/2 and 5-LOX, suppressing the expression of TNF- $\alpha$, IL-6, IL-1 $\beta$, MPO, MDA, CINC-1, MIP-2, ICAM-1 and MMP-9 and enhancing the levels of $\mathrm{mCD} 14$, nitric oxide and inducible nitric oxide synthase. Emodin has been shown to exhibit potential therapeutic effects in the treatment and prevention of various inflammatory disorders.

\section{Antivirus activity}

Severe acute respiratory syndrome (SARS) is an emerging infectious disease caused by a novel coronavirus (Ho et al., 2007). In a model of Xenopus oocytes, emodin could inhibit the $3 \mathrm{a}$ ion channel of coronavirus SARS$\mathrm{CoV}$ and $\mathrm{HCoV}-\mathrm{OC} 43$ and inhibit virus release from $\mathrm{HCoV}-\mathrm{OC} 43$ with a $\mathrm{K}_{1 / 2}$ value of approximately $20 \mu \mathrm{M}$ (Schwarz et al., 2011). Moreover, emodin significantly blocked the $\mathrm{S}$ protein and ACE2 interactions in a dose-dependent manner and inhibited the infectivity of $\mathrm{S}$ protein-pseudotyped retrovirus to Vero E6 cells. The results suggested that emodin might be considered as a potential lead therapeutic agent in the treatment of SARS (Ho et al., 2007). Dang et al., for the first time, demonstrated that emodin had a weak but long-lasting inhibitory effect on $\mathrm{HBV}$ replication in vivo (Dang et al., 2009). In vitro experiments showed that exposure of HepG-2 cells to emodin resulted in time-dependent and concentration-dependent inhibition of hepatitis $\mathrm{B}$ virus DNA replication and hepatitis $B$ surface antigen secretion (Dang et al., 2006). Similarly, emodin reduced Coxsackievirus $\mathrm{B}_{4}$ entry and replication on HepG-2 cells in a concentration-dependent and time-dependent manner. The results implied that emodin might act as a biological synthesis inhibitor against Coxsackievirus $B_{4}$ infection rather than directly inactivating the viruses or blocking their absorption to the susceptible cells (Liu et al., 2013). In a biochemical assay, emodin specifically inhibited the nuclease activity of herpes simplex virus1 UL12 alkaline nuclease. Furthermore, emodin possessed antiviral activities through the disruption of the phospholipid bilayer and the inhibition of CK2 (Hsiang and Ho, 2008).

Therefore, these results suggest that emodin might be a potent viral inhibitor with a broad spectrum of antiviral activities, indicating that emodin might act as an antiviral drug by blocking virus infection and replication in a time-dependent and concentration-dependent manner.

\section{Antibacterial activity}

Emodin exhibited a remarkable bacteriostatic effect on the Gram-positive bacteria tested, especially Bacillus subtilis and Staphylococcus aureus. The bioactive minimum inhibitory concentration (MIC) values of emodin were 28.9 and $14.4 \mu \mathrm{M}$. However, emodin was not active against two Gram-negative bacteria (Klebsiella pneumoniae and Escherichia coli) at the highest concentration $(1851.9 \mu \mathrm{M})$ tested (Chukwujekwu et al., 2006). Similarly, emodin has been reported to exhibit antimycobacterial and broad spectrum antibacterial activity, particularly against M.tuberculosis (lowest $\mathrm{MIC}=0.9 \mu \mathrm{M}$ ) and Gram-positive bacteria (lowest $\mathrm{MIC}<14.8 \mu \mathrm{M}$ ) of clinical origin (Dey et al., 2014). Cao et al. investigated the anti-methicillin-resistant $S$. aureus (anti-MRSA) activity and chemical compositions of ether extracts from Rhizoma Polygoni Cuspidati (ET-RPC). The results showed that ET-RPC could significantly inhibit bacterial growth of MRSA strains. Moreover, emodin was identified as the major compound with anti-MRSA activity, which was related to the destruction of the integrity of the cell wall and cell membrane (Cao et al., 2015).

Emodin also significantly attenuated the growth, acid production and insoluble glucan synthesis of Streptococcus mutans in vitro and suppressed the development of dental caries in rats. The results suggested that the natural compound emodin might be a novel pharmacological agent for the prevention and treatment of dental caries (Xu et al., 2014). Chen et al. reported for the first time that emodin functioned as a competitive inhibitor against Helicobacter pylori, which might be associated with occupying the entrance of the tunnel or embedding into the tunnel to prevent the substrate from accessing the active site (Chen et al., 2009b).

Overall, like many herbal monomers, emodin has a potential antimicrobial property. Emodin itself could 
be used as a potential lead compound for further anti-bacterial drug discovery.

\section{Anti-allergic activity}

Allergic reactions are triggered when allergens crosslink with the high-affinity IgE receptor (FceRI) on mast cells. To assess the anti-allergic activity of emodin, an in vivo passive anaphylaxis animal model and in vitro mouse bone marrow-derived mast cells were used to investigate the mechanism of its action on mast cells. The results demonstrated that emodin attenuated the mast cell-dependent passive anaphylactic reaction in $\mathrm{IgE}$ sensitized mice. Therefore, emodin inhibited mast cell activation and thereby the anaphylactic reaction through the suppression of the receptor-proximal Sykdependent signalling pathways (Lu et al., 2011).

An increase in the intracellular calcium $\left(\mathrm{Ca}^{2+}\right)$ concentration also triggers degranulation, bypassing receptor activation. Emodin significantly inhibited TNF- $\alpha$ production and degranulation through the regulation of IKK2 and PKC activation, suggesting that emodin inhibits mast cell activation through the FceRI-mediated proximal signalling pathway and through the $\mathrm{Ca}^{2+}$ influx-mediated downstream signalling pathway (Kim et al., 2014a). In rat basophilic leukaemia (RBL-2H3) cells, Wang et al. evaluated the inhibitory effects of emodin on the IgE-mediated allergic response by measuring the release of granules and cytokines. Emodin suppressed degranulation and cytokine production by increasing the stability of the cell membrane and inhibiting extracellular $\mathrm{Ca}^{2+}$ influx (Wang et al., 2012b).

Emodin significantly suppresses mast cell degranulation by either FceRI or calcium ionophore stimulation, suggesting that emodin could be further developed as a therapeutic agent for immediate and chronic allergic diseases.

\section{Neuroprotective activity}

The accumulation of $\beta$-amyloid protein $(A \beta)$ in the brain plays an important role in the pathogenesis of AD. Emodin up-regulated Bcl-2 and also blockaded amyloid- $325-35$-induced autophagy through the activation of the ER/PI3K/Akt pathway and the class III phosphatidylinositol 3-kinase/Beclin-1/B-cell lymphoma 2 pathway, respectively (Liu et al., 2010; Sun and Liu, 2015b). The results provided confirmatory evidence for the application of emodin in the prevention and treatment of AD. Furthermore, emodin raised the survival rate of oxygen-glucose-deprived neuron-like cells, increased activin A expression and decreased caspase-3 expression, indicating that emodin could inhibit neuronal apoptosis and alleviate nerve cell injury after oxygenglucose deprivation through the activin A pathway (Guo et al., 2013a). Yang et al. observed the interventional effects of emodin in epileptic rats and elucidated a possible mechanism of action. The findings suggested that emodin could influence the effects of cyclooxygenase- 2 in brain tissue and block $N$-methyl-Daspartate-mediated overexpression of MDR1, thereby achieving anti-epileptic effects (Yang et al., 2015).

In chronic unpredictable mild stress mice, emodin treatment $(20,40$ and $80 \mathrm{mg} / \mathrm{kg})$ reversed the behavioural deficiency. Emodin normalized the change of the plasma corticosterone level and up-regulated the hippocampal glucocorticoid receptor (GR) (mRNA and protein) and brain-derived neurotrophic factor (BDNF) (mRNA) expression levels ( $\mathrm{Li}$ et al., 2014a). It was shown for the first time that emodin treatment led to induced neurite outgrowth through the PI3K/Akt/GSK-3 $\beta$ signalling pathway in Neuro2a cells (Park et al., 2015). Zhou et al. demonstrated that emodin induced BV-2 cell apoptosis and consequently eliminated inflammatory microglia through the induction of TRB3, suggesting that emodin is a candidate for treating intracerebral haemorrhages and other neurodegenerative disorders that involve microglial activation (Zhou et al., 2011). The $\mathrm{P} 2 \mathrm{X}_{2 / 3}$ receptors play a crucial role in facilitating the transmission of pain in neuropathic pain states. Emodin could decrease the expression of the $\mathrm{P} 2 \mathrm{X}_{2 / 3}$ receptor during chronic pain and inhibit primary afferent transmission mediated by the $\mathrm{P} 2 \mathrm{X}_{2 / 3}$ receptor (Gao et al., 2011).

Based on the aforementioned studies, emodin could act as an effective neuroprotective drug for treating AD and epilepsy and could antagonize ischemiareperfusion brain injury and glutamate-induced neuronal damage.

\section{Immunosuppressive activity}

Emodin has been developed as an immunosuppressive agent. Emodin $(1,10$ and $100 \mu \mathrm{M})$ was observed to exert immunosuppressive actions by inhibiting the growth of human $\mathrm{T}$ cells and inducing apoptosis in a dosedependent and time-dependent manner. Furthermore, emodin disrupted the mitochondrial membrane potential and increased the cytosolic level of cytochrome $\mathrm{C}$ and levels of activated cleavage fragments of caspase3, -4, and -9 in human T cells (Qu et al., 2013). In vivo and in vitro experiments showed that emodin ameliorated the proliferation of peripheral blood mononuclear cells, promoted Th2-type cytokine IL-4 and reduced the Th1-type cytokine IL-2, showing immunosuppressive potential (Liu et al., 2009b).

Emodin played a key role in the inhibition of the differentiation and maturation of dendritic cells and enhancement of Tregs production, which might be helpful for the modulation of immune rejection after liver transplantation (Zhang et al., 2012). Emodin treatment also prolonged the liver allograft survival time and inhibited histopathologic changes of acute graft rejection. The mechanisms underlying this effect might be associated with polarizing the Th1/Th2 paradigm to Th2 (Tong et al., 2011).

The studies demonstrated that emodin exerts a broad range of actions on the immune system. The potential immunosuppressive mechanism might be the suppression of lymphocyte proliferation and cytokine production, which might be helpful for the modulation of immune suppression and the induction of immune tolerance.

\section{Anti-osteoporotic activity}

Emodin has been used to treat bone diseases for thousands of years. In the mouse model of LPS-mediated 
osteoporosis, Kang et al. demonstrated that emodin treatment showed the anti-osteoporotic effect by the marked suppression of bone resorption (Kang et al., 2014). Furthermore, emodin could increase the number of osteoblasts, the bone mineral density and the connectivity density in ovariectomized mice. The gene and protein expression levels of osteogenesis markers, such as Runx2, osterix, collagen type I, osteocalcin or ALP, were up-regulated (Yang et al., 2014a). A similar study showed that emodin also increased alizarin redmineralization activity and the expression of osteogenesis markers (Runx2, osteocalcin and ALP) and activated the p38-Runx2 pathway, which enhanced osteoblast differentiation. However, emodin suppressed receptor activator of NF- $\kappa \mathrm{B}$ ligand (RANKL)-induced osteoclast differentiation of bone marrow macrophages and the bone-resorbing activity of mature osteoclasts by inhibiting RANKL-induced NF- $\kappa \mathrm{B}, \mathrm{c}-\mathrm{Fos}$ and NFATc1 expression (Kim et al., 2014c). In another study, Lee et al. reported that emodin at low concentrations could accelerate the osteoblast differentiation by the induction of the BMP-2 gene by activating the PI3K-Akt and/or MAP kinase-NF- $\mathrm{BB}$ signalling pathways (Lee et al., 2008).

Summarizing the beneficial effect of emodin on bone health, our studies elucidate the pharmacological roles of emodin in the prevention of osteoporosis and provide the initiative in the early drug discovery and development for osteoporosis.

\section{Anti-diabetic activity}

Recent studies have suggested that emodin has a PPAR $\gamma$-activating effect. Intraperitoneal injections with emodin for 3 weeks notably ameliorated the symptoms of diabetic animals, and this effect was likely associated with the regulation of the PPAR $\gamma$ pathway (Xue et al., 2010). A similar study showed that emodin effectively ameliorated p38 over-activation and hypocontractility in high glucose-induced mesangial cells via activation of PPAR $\gamma$ (Liu et al., 2009a). In differentiated 3 T3-L1 adipocytes, emodin exhibited a high binding affinity to PPAR $\gamma$ by inducing an increase in glucose uptake and increases in GLUT1 and GLUT4 mRNA expression (Yang et al., 2007).

Emodin has been reported to be a novel AMPactivated protein kinase (AMPK) activator. Emodin had a positive effect on glucose metabolism in 3 T3-L1 adipocytes, which was primarily due to increases in glycolysis and might be mediated by the AMPK signalling pathway (Zhang et al., 2015b). Chen and Song et al. also demonstrated that emodin regulated glucose utilization through activating the AMPK signalling pathway (Chen et al., 2012; Song et al., 2013). Moreover, emodin displayed an inhibitory effect on the high-level glucose-induced phosphorylation of ERK 1/2 and p38 MAPK (Gao et al., 2015). Wang et al. demonstrated that long-term emodin $(3 \mu \mathrm{M})$ administration improved glucose tolerance and ameliorated other metabolic disor-

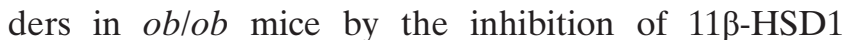
activity in adipose tissue (Wang et al., 2012c). Emodin has been reported to exhibit protective effects against diabetic cardiomyopathy by regulating the AKT/GSK$3 \beta$ signalling pathway (Wu et al., 2014).
Diabetic nephropathy (DN) is a major cause of endstage renal disease (Baylis et al., 2003). Emodin (40 mg/ $\mathrm{kg} /$ day) was efficient to ameliorate renal dysfunction in DN rats likely by its inhibition of the activation of the p38 MAPK pathway and down-regulation of the expression of fibronectin (Wang et al., 2006). Yang et al. also reported that emodin significantly decreased NF$\kappa \mathrm{B}$-mediated TGF- $\beta 1$ and fibronectin expression (Yang et al., 2013). Furthermore, emodin $(20 \mathrm{mg} / \mathrm{kg} / \mathrm{day})$ repressed renal integrin-linked kinase and desmin expression, preserved nephrin expression and ameliorated albuminuria in streptozotocin-induced diabetic rats (Chen et al., 2015b). In rat mesangial cells cultured under high glucose, emodin suppressed hyperglycaemiainduced cell proliferation and fibronectin expression by inhibiting the p38MAPK pathway and cellular FLICE-inhibitory protein (cFLIP), suggesting a potential role of emodin in the treatment of DN (Gao et al., 2014; Li et al., 2009).

In summary, our results show that emodin ameliorates the symptoms of diabetic animals, and this effect is likely associated with the activation of the PPAR $\gamma$ and AMPK signalling pathways. Therefore, emodin holds great promise for the eventual use of a therapeutic agent to treat diabetes mellitus and its complications.

\section{Hepatoprotective activity}

Emodin was found to ameliorate ethanol-mediated liver steatosis and decrease alanine aminotransferase (ALT), aspartate aminotransferase and hepatic triglycerides. Moreover, emodin significantly reduced liver $\alpha$-smooth muscle actin and collagen type I, whereas it increased the mRNA levels of PPAR- $\gamma$ (Liu et al., 2014). In another experiment, emodin was shown to attenuate the ethanol-induced cytotoxicity of HepG2/CYP2E1 cells by the inhibition of Gamma-glutamyltransferase (GGT) activity and CYP2E1 protein expression in a dose-dependent manner, indicating that emodin might be beneficial in patients with alcoholic liver disease (Qian et al., 2011). In a rat model with $\mathrm{CCl}_{4}$-induced liver fibrogenesis, the activities of serum ALT and aspartate aminotransferase and the hepatic hydroxyproline content were significantly reduced by the administration of emodin. The mRNA and protein levels of TGF- $\beta 1$, Smad 4 and $\alpha$-SMA were also down-regulated in liver tissues (Dong et al., 2009). Lee et al. demonstrated that emodin might be valuable for the protection of $\mathrm{CCl}_{4}$-induced liver injury by reducing lipid peroxidation and by positively modulating inflammation (Lee et al., 2012). Emodin also had the ability to prevent $\mathrm{CCl}_{4}$-induced liver damage through reversing hepatic oxidative insults, CYP enzymatic activity and ultrastructural changes (Bhadauria et al., 2009). In addition, emodin at a dose of $30 \mathrm{mg} / \mathrm{kg}$ (po) possessed optimum hepatoprotective ability against acetaminophen (APAP)-induced toxicity via diminishing oxidative stress (Bhadauria, 2010).

Yin et al. showed that emodin could effectively prevent LPS-induced fulminant hepatic failure, and this beneficial effect might occur by the blockade of TLR4/MD2 complex expression on the cell surface of macrophages, which could lead to the deactivation of the $\mathrm{p} 38$ MAPK and NF- $\mathrm{KB}$ signalling pathways and inhibition of TNF- $\alpha$ production (Yin et al., 2014). Similarly, emodin treatment protected against concanavalin 
A-induced liver injury by inhibiting the activation of the p38 MAPK and NF- $\mathrm{B}$ signalling pathways in CD4+ T cells and macrophages, indicating that emodin can be applied as a potential candidate for the prevention and intervention of clinical fulminant hepatic failure (Xue et al., 2015).

We may be able to conclude from these findings that emodin exhibits hepatoprotective effects in ethanolinduced hepatosteatosis and $\mathrm{CCl}_{4}$ or APAP-induced liver injury, indicating that emodin might have therapeutic applications in the prevention of fulminant hepatitis.

\section{TOXICITY}

Through in vivo and in vitro experiments, Wang et al. investigated the toxicity and target organs of rhubarb in the rat and compared the toxicity of the essential components of rhubarb. In these studies, emodin was the primary toxic component of rhubarb, and the toxic target organs were predicted to be the kidney and liver (Wang et al., 2007b). Emodin $(30 \mu \mathrm{M})$ led to significant apoptosis in a time-dependent manner, as determined by morphological changes in L-02 cells ( $\mathrm{Li}$ et al., 2012a). Furthermore, emodin had the potential to disturb glutathione (GSH) and fatty acid metabolism in human liver cells (Liu et al., 2015). In addition, emodin exerted its cytotoxic effects in the hepatic cells of grass carp via apoptosis by directly affecting the mitochondria, indicating that high concentrations of emodin are not suitable for use in fish (Cui et al., 2014).

The US National Toxicology Program showed that emodin exposure resulted in increased incidences of renal tubule pigmentation in male and female mice and increased incidences of nephropathy in female mice (National Toxicology Program, 2001). The administration of emodin $(40$ and $80 \mu \mathrm{M})$ for $24 \mathrm{~h}$ resulted in a significant decrease in cell viability by approximately $29 \%$ and $45 \%$, respectively, which was mediated through the induction of apoptosis in the caspase 3-dependent pathway and the mitochondrial pathway (Wang et al., 2007a, 2015a). Another study demonstrated that emodin also significantly inhibited the proliferation of HK-2 cells, with $\mathrm{IC}_{50}$ values of $130.65 \mu \mathrm{M}$ (Wang et al., 2007c).

Emodin has been reported to exert reproductive toxicity. In male reproductive organs/tissues, the toxicity study of emodin indicated that it has testicular toxicity because of the disruption of the expression of testicular genes (Oshida et al., 2011). Luo et al. demonstrated that emodin also inhibited human sperm functions by reducing sperm $\left[\mathrm{Ca}^{2+}\right] \mathrm{i}$ and suppressing tyrosine phosphorylation in vitro (Luo et al., 2015). Ethanol solution extracts of $R$.patientia, which contain anthraquinones, such as emodin and chrysophanol, as active ingredients, caused irreversible pathological changes at very high doses (4000 mg/kg), although lower doses and aqueous extracts produced either non-significant or reversible changes (Islam et al., 2015). Therefore, long-term administration of high doses of anthraquinones extracts should be avoided altogether during pregnancy.

Li et al. found that emodin possessed genotoxicity and DNA-damaging properties by stabilizing Topo II-DNA cleavage complexes and inhibiting ATP hydrolysis (Li et al., 2010). Moreover, emodin exerted a toxic function on interstitial cells of Cajal, which could lead to membrane damage and energy metabolism disorders by inhibiting the activity of $\mathrm{Na}^{+}-\mathrm{K}^{+}$-ATPase and $\mathrm{Ca} 2^{+}$ATPase and increasing the activity of IP3 and cAMP (Peng et al., 2013).

\section{PHARMACOKINETICS}

In pharmacokinetic experiments, emodin was predominantly found in the liver and the brain after oral intake of P. cuspidatum (Lin et al., 2012). After intragastric administration at doses of 20 and $40 \mathrm{mg} / \mathrm{kg}$, emodin rapidly underwent phase II metabolism to form its glucuronide, and the parent form of emodin was almost undetectable in vivo. Even when administered at higher dose $(82.4 \mathrm{mg} /$ $\mathrm{kg}$ ), the in vivo emodin levels detected remained very low (Shia et al., 2010). In a Caco-2 cell culture model, Liu et al. demonstrated that glucuronidation metabolism appeared to be one of the main reasons for the very poor oral bioavailability of emodin (Liu et al., 2012). Moreover, Ma et al. was the first to demonstrate that 2,3,5,4'tetrahydroxystilbene-2-O- $\beta$-D-glucoside (TSG) could inhibit the phase II metabolism of emodin in vivo through down-regulation of the expression of UGT1A8 (Ma et al., 2013). A similar study showed that piperine significantly increased the $\mathrm{C}_{\max }$ and area under concentrationtime curve (AUC) of emodin and decreased the AUC and $\mathrm{C}_{\max }$ of emodin glucuronide. However, the detailed mechanisms of the improved bioavailability of emodin need to be further investigated (Di et al., 2015). Traditional oral administration would not be the best method of application of emodin because of poor intestinal absorption, fast elimination and low bioavailability in vivo. The pharmacokinetics of emodin could be improved by inhibiting its glucuronidation metabolism. In further research, we should pay attention to the ability of emodin to lead to other toxicity problems due to the increase in its content.

\section{Future perspectives and conclusions}

Emodin, the major bioactive ingredient of R. palmatum, is available in common foods and is used as an alternative medicine. In vitro and in vivo pharmacological studies have revealed that emodin exhibits a variety of pharmacological benefits, including anticancer, antiinflammatory, antivirus, antibacterial, anti-allergic, anti-osteoporotic, anti-diabetic, immunosuppressive, neuroprotective and hepatoprotective effects. Emodin has been widely used in the treatment of cancer, asthma, osteoarthritis, diabetes, atherosclerosis, AD and hepatic disease. Furthermore, many recent studies have shown that emodin in conjunction with various chemotherapeutic agents is effective in the elimination of tumour cell growth. Therefore, it is important to evaluate the effect of emodin on other drug metabolism before emodin can be safely used in combination with other drugs.

Emodin strongly inhibits the expression of proteins and genes, such as C-MYC, MCL1, CCND1, CK2, IKK2, PKC, TGF- $\beta 1$, Smad4 and Bcl-2/Bax. However, the expression levels of BDNF, Runx2, osterix, collagen type I, osteocalcin and ALP are up-regulated. Moreover, emodin affects the NF- $\kappa$ B, MAPK, PI3K/AKT, NIK-IKK, PPAR $\gamma$, MMPs and activin A signalling pathways. The evidence provided strongly supports the 
Table 1. Pharmacology of emodin

\begin{tabular}{|c|c|c|c|c|}
\hline Pharmacological effect & Cell lines/model & Activity/mechanism(s) of action & Application & Reference \\
\hline \multirow[t]{12}{*}{ Anticancer activity } & Bladder cancer cell & Modulates epigenetic modifications & In vitro & Cha et al. (2015) \\
\hline & Human lung adenocarcinoma & Modifies the extrinsic apoptotic & In vitro & Li et al. (2014b) \\
\hline & A549 cells & pathways and induces cell cycle arrest & & \\
\hline & OECM- 1 cells & Inhibits the $\beta$-catenin and Akt pathways & $\begin{array}{l}\text { In vitro } \\
\text { In vivo }\end{array}$ & Way et al. (2014) \\
\hline & Glioma stem cells & Inhibits the stemness signalling & In vitro & Kim et al. (2014b) \\
\hline & $\begin{array}{l}\text { Human cervical cancer HeLa } \\
\text { cells }\end{array}$ & $\begin{array}{l}\text { Intrinsic mitochondrial pathway; extrinsic } \\
\text { death receptor pathway }\end{array}$ & In vivo & Wang et al. (2013) \\
\hline & Human breast cancer cell & $\begin{array}{l}\text { Inhibits the P2X7 receptor;down-regulates } \\
\text { ER } \alpha \text { protein levels, MCL1, CCND1, C-MYC, } \\
\text { MMP-2, MMP-9, UPA and UPAR expression; } \\
\text { reduces STAT6 phosphorylation and C/EBP } \beta \\
\text { expression; and increases the expression of } \\
\text { miR-34a }\end{array}$ & $\begin{array}{l}\text { In vitro } \\
\text { In vivo }\end{array}$ & $\begin{array}{l}\text { Wang et al. (2013); } \\
\text { Huang et al. (2013); } \\
\text { Guo et al. (2013b); } \\
\text { Li et al. (2013b); } \\
\text { Jia et al. (2014b); } \\
\text { Sun et al. (2015a) }\end{array}$ \\
\hline & Human colon cancer cell & $\begin{array}{l}\text { Mitochondrial apoptosis pathway; } \\
\text { p53-mitochondrial apoptotic pathway; } \\
\text { Down-regulates TCF/LEF transcriptional } \\
\text { activity, cell survival proteins, CXCR4 } \\
\text { expression Induces death receptors }\end{array}$ & $\begin{array}{l}\text { In vitro } \\
\text { In vivo }\end{array}$ & $\begin{array}{l}\text { Xie et al. (2014); } \\
\text { Ma and Li (2014a); } \\
\text { Pooja and Karunagaran } \\
\text { (2014); } \\
\text { Subramaniam et al. } \\
\text { (2013); } \\
\text { Manu et al. (2013) }\end{array}$ \\
\hline & $\begin{array}{l}\text { Human ovarian carcinoma } \\
\text { cell }\end{array}$ & Down-regulates MRP1 expression & In vivo & Ma et al. (2014b) \\
\hline & Gallbladder carcinoma cell & Down-regulates ABCG2 expression & In vivo & Li et al. (2012b) \\
\hline & Gastric cancer cells & Induces apoptosis; Induces cell cycle arrest & In vitro & Huang et al. (2015) \\
\hline & K562/ADM cells & $\begin{array}{l}\text { Decreased MDR1 mRNA/p-gp protein } \\
\text { expression }\end{array}$ & In vitro & Chen et al. (2013) \\
\hline \multirow{8}{*}{ Antiinflammatory activity } & Severe acute pancreatitis & Inhibits ER stress transducers $\operatorname{IRE} 1 \alpha$ and its & In vitro & Wu et al. (2013); \\
\hline & model & 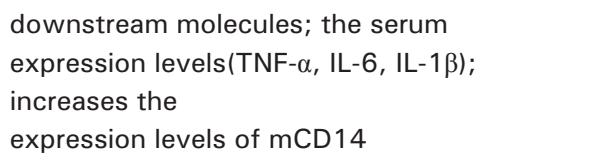 & In vivo & $\begin{array}{l}\text { Xia et al. (2010); } \\
\text { Ni et al. (2014); } \\
\text { Yao et al. (2015) }\end{array}$ \\
\hline & $\begin{array}{l}\text { Collagen-induced arthritic } \\
\text { mice model }\end{array}$ & $\begin{array}{l}\text { Inhibits the NF-кB pathway; pro-inflammatory } \\
\text { mediators }\end{array}$ & In vivo & $\begin{array}{l}\text { Huang et al. (2013); } \\
\text { Zhu et al. (2013) }\end{array}$ \\
\hline & LPS-induced mouse mastitis & Activates PPAR- $\gamma$ & In vivo & $\begin{array}{l}\text { Yang et al. (2014b); } \\
\text { Li et al. (2013a) }\end{array}$ \\
\hline & $\begin{array}{l}\text { LPS-induced mouse corneal } \\
\text { injury }\end{array}$ & $\begin{array}{l}\text { Suppresses the activation of NF-KB, JNK and } \\
\text { the expression of ICAM-1 }\end{array}$ & $\begin{array}{l}\text { In vitro } \\
\text { In vivo }\end{array}$ & $\begin{array}{l}\text { Kitano et al. (2007); } \\
\text { Chen et al. (2009a); } \\
\text { Chen et al. (2015a) }\end{array}$ \\
\hline & $\begin{array}{l}\text { Non-alcoholic steatohepatitis } \\
\text { model }\end{array}$ & Suppresses Erk $1 / 2$ and p38 signalling & In vitro & Jia et al. (2014a) \\
\hline & $\begin{array}{l}\text { Ovalbumin-induced mouse } \\
\text { model }\end{array}$ & $\begin{array}{l}\text { Suppresses MMP-9 expression; Induces HO-1 } \\
\text { expression }\end{array}$ & In vivo & Wang et al. (2015b) \\
\hline & $\begin{array}{l}\text { Atopic dermatitis mouse } \\
\text { model }\end{array}$ & Inhibits 5-LOX action & In vivo & Jin et al. (2011) \\
\hline \multirow[t]{4}{*}{ Antivirus activity } & Vero E6 cells & Blocks the S protein and ACE2 interaction & In vitro & Ho et al. (2007) \\
\hline & Rhabdomyosarcoma cells & $\begin{array}{l}\text { Inhibits the } 3 \mathrm{a} \text { ion channel of coronavirus } \\
\text { SARS-CoV and HCoV-OC } 43\end{array}$ & In vitro & Schwarz et al. (2011) \\
\hline & $\begin{array}{l}\text { Human hepatoma } 2.2 .15 \\
\text { cells }\end{array}$ & Inhibits the replication of hepatitis B virus & $\begin{array}{l}\text { In vitro } \\
\text { In vivo }\end{array}$ & $\begin{array}{l}\text { Dang et al. (2006); } \\
\text { Dang et al. (2009) }\end{array}$ \\
\hline & $\begin{array}{l}\text { African green monkey } \\
\text { kidney cells }\end{array}$ & $\begin{array}{l}\text { Disrupts phospholipid bilayer; inhibits CK2 } \\
\text { and UL12 }\end{array}$ & In vitro & Hsiang and $\mathrm{Ho}(2008)$ \\
\hline \multirow[t]{3}{*}{ Antibacterial activity } & $\begin{array}{l}\text { The bacterial strain } \\
\text { MRSA } 252\end{array}$ & $\begin{array}{l}\text { Destructs the integrity of the cell wall and } \\
\text { cell membrane }\end{array}$ & In vitro & Cao et al. (2015) \\
\hline & S. mutans ATCC 25175 & $\begin{array}{l}\text { Suppressed the synthesis of insoluble } \\
\text { glucans }\end{array}$ & $\begin{array}{l}\text { In vitro } \\
\text { In vivo }\end{array}$ & Xu et al. (2014) \\
\hline & $\begin{array}{l}\text { Standard H.pylori strains } \\
\text { SS1 and ATCC } 43504\end{array}$ & $\begin{array}{l}\text { Occupies the entrance of the tunnel or } \\
\text { embeds into the tunnel }\end{array}$ & In vitro & Chen et al. (2009b) \\
\hline \multirow[t]{2}{*}{ Anti-allergic activity } & RBL-2H3 cells & $\begin{array}{l}\text { Increases the stability of the cell membrane; } \\
\text { inhibits extracellular } \mathrm{Ca}^{2+} \text { influx }\end{array}$ & In vitro & Wang et al. (2012b) \\
\hline & Female C57BL/6 mice & Inhibits the PKC or PKC-IKK2 pathways & In vivo & Kim et al. (2014a) \\
\hline
\end{tabular}


Table 1. (Continued)

\begin{tabular}{|c|c|c|c|c|}
\hline Pharmacological effect & Cell lines/model & Activity/mechanism(s) of action & Application & Reference \\
\hline \multirow[t]{8}{*}{ Neuroprotective activity } & Cortical neurons cell & Activates ER/PI3K/Akt pathway & In vitro & Liu et al. (2010) \\
\hline & PC12 cells & $\begin{array}{l}\text { Activates class III phosphatidylinositol } \\
\text { 3-kinase/Beclin-1/ B-cell lymphoma } 2 \text { pathway }\end{array}$ & In vitro & Sun and Liu (2015b) \\
\hline & Neuro2a cells & $\mathrm{PI} 3 \mathrm{~K} / \mathrm{Akt} / \mathrm{GSK}-3 \beta$ signalling pathway & In vitro & Park et al. (2015) \\
\hline & ICR mice & Up-regulates GR and BDNF levels & In vivo & Li et al. (2014a) \\
\hline & Rat epilepsy model & Inhibits MDR1 gene and its associated genes & In vivo & Yang et al. (2015) \\
\hline & PC12 cells & Activin A pathway & In vitro & Guo et al. (2013a) \\
\hline & BV-2 cells & Eliminates inflammatory microglia & In vitro & Zhou et al. (2011) \\
\hline & $\begin{array}{l}\text { Chronic constriction injury } \\
\text { (CCI) model }\end{array}$ & $\mathrm{P} 2 \mathrm{X}_{2 / 3}$ receptor & $\begin{array}{l}\text { In vitro } \\
\text { In vivo }\end{array}$ & Gao et al. (2011) \\
\hline \multirow[t]{4}{*}{$\begin{array}{l}\text { Immunosuppressive } \\
\text { activity }\end{array}$} & Human T cells & $\begin{array}{l}\text { ROS-mediated ER stress; mitochondrial } \\
\text { dysfunction }\end{array}$ & In vitro & Qu et al. (2013) \\
\hline & Dendritic cells (DCs) & $\begin{array}{l}\text { Inhibits the differentiation and maturation } \\
\text { of DCs }\end{array}$ & In vitro & Zhang et al. (2012) \\
\hline & $\begin{array}{l}\text { Liver transplantation rats } \\
\text { model }\end{array}$ & $\begin{array}{l}\text { Modulated the deviation of the Th1/Th2 } \\
\text { paradigm } \\
\text { to Th2 }\end{array}$ & In vitro & Tong et al. (2011) \\
\hline & $\begin{array}{l}\text { Peripheral blood mononuclear } \\
\text { cell }\end{array}$ & Suppresses lymphocyte proliferation & $\begin{array}{l}\text { In vitro } \\
\text { In vivo }\end{array}$ & Liu et al. (2009b) \\
\hline \multirow[t]{3}{*}{ Anti-osteoporotic activity } & $\begin{array}{l}\text { LPS-mediated osteoporotic } \\
\text { mouse model }\end{array}$ & Suppresses bone resorption & In vitro & Kang et al. (2014) \\
\hline & Bone marrow cell & $\begin{array}{l}\text { Up-regulates Runx2, osterix, collagen type } \\
\text { I, osteocalcin and ALP;down-regulates } \\
\text { adipogenesis, PPAR } \gamma, \mathrm{C} / \mathrm{EBP} \alpha \text { and ap2 }\end{array}$ & $\begin{array}{l}\text { In vitro } \\
\text { In vivo }\end{array}$ & $\begin{array}{l}\text { Kim et al. (2014c); } \\
\text { Yang et al. (2014a) }\end{array}$ \\
\hline & $\begin{array}{l}\text { Mouse osteoblastic MC3 } \\
\text { T3-E1 subclone } 4 \text { cells }\end{array}$ & $\begin{array}{l}\text { Activates the PI3K-Akt; MAP kinase-NF-kB } \\
\text { signalling pathways }\end{array}$ & In vitro & Lee et al. (2008) \\
\hline \multirow[t]{11}{*}{ Anti-diabetic activity } & STZ-induced diabetic mice & Regulates the PPAR $\gamma$ pathway & In vivo & Xue et al. (2010) \\
\hline & $\begin{array}{l}\text { High-glucose-induced } \\
\text { mesangial cells }\end{array}$ & Activates the PPAR $\gamma$ pathway & In vitro & Liu et al. (2009a) \\
\hline & 3 T3-LI cells & $\begin{array}{l}\text { Promotes adipocyte differentiation; } \\
\text { increases glucose uptake }\end{array}$ & In vitro & Yang et al. (2007) \\
\hline & $\begin{array}{l}\text { 3 T3-L1 preadipocytesC57BI/6 } \\
\text { J mice }\end{array}$ & 6 Activates the AMPK signalling pathway & $\begin{array}{l}\text { In vitro } \\
\text { In vivo }\end{array}$ & $\begin{array}{l}\text { Chen et al. (2012); } \\
\text { Song et al. (2013) }\end{array}$ \\
\hline & $\begin{array}{l}\text { Human umbilical vein } \\
\text { endothelial cells }\end{array}$ & $\begin{array}{l}\text { Suppresses activation of p38 MAPK and } \\
\text { ERK } 1 / 2\end{array}$ & In vitro & Gao et al. (2015) \\
\hline & 3 T3-L1 adipocytes & Inhibits NF-KB, ERK signalling pathways & $\begin{array}{l}\text { In vitro } \\
\text { In vivo }\end{array}$ & Zhang et al. (2015b) \\
\hline & Mesangial cells & $\begin{array}{l}\text { Inhibits NF-kB;inhibits cellular FLICE-inhibitory } \\
\text { protein generation }\end{array}$ & In vitro & $\begin{array}{l}\text { Yang et al. (2013); } \\
\text { Gao et al. (2014) }\end{array}$ \\
\hline & In ob/ob mice & Inhibits the $11 \beta$-HSD 1 activity & $\begin{array}{l}\text { In vitro } \\
\text { In vivo }\end{array}$ & Wang et al. (2012c) \\
\hline & $\begin{array}{l}\text { STZ-induced diabetic rats } \\
\text { with cardiomyopathy }\end{array}$ & Regulates the AKT/GSK-3 $\beta$ signalling pathway & In vivo & Wu et al. (2014) \\
\hline & $\begin{array}{l}\text { STZ-induced diabetic rats } \\
\text { with nephropathy }\end{array}$ & Inhibits the activation of p38 MAPK pathway & In vivo & Wang et al. (2006) \\
\hline & $\begin{array}{l}\text { HG-stimulated podocytes; } \\
\text { STZ-induced diabetic rats }\end{array}$ & $\begin{array}{l}\text { Inhibits ILK and desmin expression; restores } \\
\text { nephrin expression }\end{array}$ & $\begin{array}{l}\text { In vitro } \\
\text { In vivo }\end{array}$ & Chen et al. (2015b) \\
\hline \multirow[t]{6}{*}{ Hepatoprotective activity } & $\begin{array}{l}\text { LPS-elicited RAW } 264.7 \\
\text { mouse macrophage cells }\end{array}$ & $\begin{array}{l}\text { Inhibits TNF- } \alpha \text { production; deactivates MAPKs } \\
\text { and NF- } \mathrm{KB} \text {; blockades TLR4/MD2 } \\
\text { complex expression }\end{array}$ & $\begin{array}{l}\text { In vitro } \\
\text { In vivo }\end{array}$ & Yin et al. (2014) \\
\hline & $\begin{array}{l}\mathrm{CD} 4+\mathrm{T} \text { cells and } \\
\text { macrophages }\end{array}$ & $\begin{array}{l}\text { Inhibits activation of the p38 MAPK-NF-KB } \\
\text { signalling pathway }\end{array}$ & $\begin{array}{l}\text { In vitro } \\
\text { In vivo }\end{array}$ & Xue et al. (2015) \\
\hline & $\begin{array}{l}\mathrm{CCl}_{4} \text {-induced hepatic damage } \\
\text { in rats }\end{array}$ & $\begin{array}{l}\text { Reverses hepatic oxidative insult, CYP } \\
\text { enzymatic activity and ultrastructural } \\
\text { changes }\end{array}$ & In vivo & Bhadauria et al. (2009) \\
\hline & $\begin{array}{l}\text { Clone } 9 \text { cell; } \mathrm{CCl}_{4} \text {-induced } \\
\text { liver damage of } \mathrm{SD} \text { rats }\end{array}$ & Modulates inflammation & In vivo & Lee et al. (2012) \\
\hline & $\begin{array}{l}\text { APAP-induced hepatic } \\
\text { damage in rats }\end{array}$ & Diminishes oxidative stress & In vivo & Bhadauria (2010) \\
\hline & HepG2/CYP2E1 cells & $\begin{array}{l}\text { Inhibits the GGT activity and CYP2E1 protein } \\
\text { expression }\end{array}$ & In vitro & Qian et al. (2011) \\
\hline
\end{tabular}


Table 2. Toxicity of emodin

\begin{tabular}{|c|c|c|c|}
\hline Cell lines/model & Activity/mechanism(s) of action & Application & Reference \\
\hline $\begin{array}{l}\text { Human proximal } \\
\text { tubular epithelial } \\
\text { (HK-2) cells }\end{array}$ & $\begin{array}{l}\text { Induces apoptosis in caspase 3-dependent pathway } \\
\text { and mitochondrial pathway }\end{array}$ & In vitro & $\begin{array}{l}\text { Wang et al. (2007a, 2007c) } \\
\text { Wang et al. (2015a) }\end{array}$ \\
\hline L8824 cells & Induces apoptosis by directly affecting the mitochondria & In vitro & Cui et al. (2014) \\
\hline L-02 cells & $\begin{array}{l}\text { Induces apoptosis GSH metabolism and fatty acid } \\
\text { metabolism pathway }\end{array}$ & In vitro & $\begin{array}{l}\text { Li et al. (2012a); } \\
\text { Liu et al. (2015) }\end{array}$ \\
\hline $\begin{array}{l}\text { TK6 cells, HL-60 cells, } \\
\text { and } \mathrm{HL}-60 / \mathrm{M} \times 2 \text { cells }\end{array}$ & $\begin{array}{l}\text { Stabilizes Topo II-DNA cleavage complexes; inhibits ATP } \\
\text { hydrolysis }\end{array}$ & In vitro & Li et al. (2010) \\
\hline Interstitial cells of Cajal & $\begin{array}{l}\text { Inhibits activity of } \mathrm{Na}^{+}-\mathrm{K}^{+}-\text {ATPase and } \mathrm{Ca}^{2+} \text {-ATPase; } \\
\text { raises activity of IP3 and cAMP }\end{array}$ & In vitro & Peng et al. (2013) \\
\hline $\begin{array}{l}\text { Male reproductive } \\
\text { organs/tissues }\end{array}$ & Disrupts the expression of testicular genes & In vivo & Oshida et al. (2011) \\
\hline Human sperm & Reduces sperm $\left[\mathrm{Ca} 2^{+}\right]_{i}$; suppresses tyrosine phosphorylation & In vitro & Luo et al. (2015) \\
\hline
\end{tabular}

ability of emodin to inhibit diverse events involved in cell apoptosis, cell metastasis and cell cycle arrest and clearly supports its traditional use in the treatment of cancers. This paper summarizes the pharmacological properties and molecular mechanisms of emodin (in Table 1) and strongly supports the view that emodin has a broad application prospect.

Rhein, which is similar to emodin, has many pharmacological properties, including hepatoprotective, nephroprotective, antiinflammatory, antioxidant, anticancer and antimicrobial activities (Zhou et al., 2015). Aloe-emodin (AE) also has attracted increasing attention for its anticancer properties. Numerous studies have revealed that $\mathrm{AE}$ exerts therapeutic effects through multiple pathways, including differentiation, apoptosis, invasion and migration (Chen et al., 2014).

Another issue is that emodin shows both hepatoprotection and hepatotoxicity, which appears to be contradictory. Based on an examination of the literature, we speculate that the reasons are for these effects are likely the administration dosage and delivery time. High doses and long-term drug delivery are more likely to result in liver toxicity, whereas low doses and shortterm drug delivery might result in liver protection. Therefore, this issue requires further study.
We also summarized the toxicity of emodin, including the hepatotoxicity, nephrotoxicity, genotoxicity and reproductive toxicity (in Table 2). The number of reports regarding the adverse effects of emodin is increasing. The primary toxicity among these reports is hepatotoxicity and nephrotoxicity, which are of wide concern worldwide. Emodin shows hepatotoxicity and nephrotoxicity by inducing apoptosis in the caspase 3dependent pathway and the mitochondrial pathway. In addition, GSH metabolism and the fatty acid metabolism pathways are also involved. Therefore, further studies are needed to attenuate the toxicity of emodin.

\section{Acknowledgements}

This work was financially supported by the Innovation Team of Beijing University of Chinese Medicine (no. 2011-CXTD-13) and the Collaborative Innovation Construction Plan of Beijing University of Chinese Medicine (no. 2013-XTCX-03).

\section{Conflict of Interest}

The authors have declared that there is no conflict of interest.

\section{REFERENCES}

Baylis C, Atzpodien EA, Freshour G, Engels K. 2003. Peroxisome proliferator-activated receptor $\gamma$ agonist provides superior renal protection versus angiotensin-converting enzyme inhibition in a rat model of type 2 diabetes with obesity. $J$ Pharmacol Exp Ther 307: 854-860.

Bhadauria M. 2010. Dose-dependent hepatoprotective effect of emodin against acetaminophen-induced acute damage in rats. Exp Toxicol Pathol 62: 627-635.

Bhadauria M, Nirala SK, Shrivastava S, et al. 2009. Emodin reverses $\mathrm{CCl}_{4}$ induced hepatic cytochrome P450 (CYP) enzymatic and ultrastructural changes: the in vivo evidence. Hepatol Res 39: 290-300.

Cao F, Peng W, Li X, et al. 2015. Emodin is identified as the active component of ether extracts from Rhizoma Polygoni Cuspidati, for anti-MRSA activity. Can J Physiol Pharm 93: 1-9.

Cha TL, Chuang MJ, Tang SH, et al. 2015. Emodin modulates epigenetic modifications and suppresses bladder carcinoma cell growth. Mol Carcinogen 54: 167-177.

Chen GL, Liu ZY, Wang J, et al. 2009a. Protective effect of emodin against lipopolysaccharides-induced corneal injury in rats. Chin Med Sci J 24: 236-240.
Chen GL, Zhang JJ, Kao X, et al. 2015a. Emodin ameliorates lipopolysaccharides-induced corneal inflammation in rats. Int J Ophthalmo/ 8: 665-669.

Chen J, Zhang L, Zhang Y, et al. 2009b. Emodin targets the $\beta$ hydroxyacyl-acyl carrier protein dehydratase from Helicobacter pylori: enzymatic inhibition assay with crystal structural and thermodynamic characterization. $B M C$ Microbiol 9: 91

Chen P, Liu Y, Sun Y, et al. 2013. AZT and emodin exhibit synergistic growth-inhibitory effects on K562/ADM cells by inducing $S$ phase cell cycle arrest and suppressing MDR1 mRNA/p-gp protein expression. Pharm Biol 51 : 1586-1591.

Chen R, Zhang JM, Hu YY, et al. 2014. Potential antineoplastic effects of Aloe-emodin: a comprehensive review. Am J Chinese Med 42: 275-288.

Chen T, Zheng LY, Xiao W, et al. 2015b. Emodin ameliorates high glucose induced-podocyte epithelial-mesenchymal transition in-vitro and in-viv. Cell Physiol Biochem 35: 1425-1436.

Chen Z, Zhang L, Yi J, et al. 2012. Promotion of adiponectin multimerization by emodin: a novel AMPK activator with PPAR $\gamma$-agonist activity. J Cell Biochem 113: 3547-3558. 
Chukwujekwu JC, Coombes PH, Mulholland DA, Staden J. 2006. Emodin, an antibacterial anthraquinone from the roots of Cassia occidentalis. S Afr J Bot 72: 295-297.

Cirillo C, Capasso R. 2015. Constipation and botanical medicines: an overview. Phytother Res 9: 1488-93.

Cui YT, Liu B, Xie J, et al. 2014. The effect of emodin on cytotoxicity, apoptosis and antioxidant capacity in the hepatic cells of grass carp (Ctenopharyngodon idellus). Fish Shellfish Immun 38: 74-79.

Dang SS, Jia XL, Song P, et al. 2009. Inhibitory effect of emodin and Astragalus polysaccharide on the replication of $\mathrm{HBV}$. World J Gastroentero 15: 5669-5673.

Dang SS, Zhang ZG, Chen YR, et al. 2006. Inhibition of the replication of hepatitis $\mathrm{B}$ virus in vitro by emodin. Am J Case Rep 12: 302-306.

Dey D, Ray R, Hazra B. 2014. Antitubercular and antibacterial activity of quinonoid natural products against multi-drug resistant clinical isolates. Phytother Res 28: 1014-1021.

Di X, Wang X, Liu Y. 2015. Effect of piperine on the bioavailability and pharmacokinetics of emodin in rats. J Pharmaceut Biomed 115: $144-149$

Ding $\mathrm{Y}$, Zhao L, Mei H, et al. 2008. Exploration of Emodin to treat alpha-naphthylisothiocyanate-induced cholestatic hepatitis via anti-inflammatory pathway. Eur J Pharmacol 590: 377-386.

Dong MX, Jia Y, Zhang YB, et al. 2009. Emodin protects rat liver from $\mathrm{CCl}_{4}$-induced fibrogenesis via inhibition of hepatic stellate cells activation. World J Gastroentero 15: 4753-4762.

Gao J, Wang F, Wang W, et al. 2014. Emodin suppresses hyperglycemia-induced proliferation and fibronectin expression in mesangial cells via inhibiting cFLIP. PLoS One 9: e93588.

Gao J, Tao J, Zhang N, et al. 2015. Formula optimization of the Jiashitang scar removal ointment and antiinflammatory compounds screening by NF- $\mathrm{B}$ bioactivity-guided dual-luciferase reporter assay system. Phytother Res 29: 241-50.

Gao Y, Liu H, Deng L, et al. 2011. Effect of emodin on neuropathic pain transmission mediated by $\mathrm{P} 2 \mathrm{X} 2 / 3$ receptor of primary sensory neurons. Brain Res Bull 84: 406-413.

Gao Y, Zhang J, Li G, et al. 2015. Protection of vascular endothelial cells from high glucose-induced cytotoxicity by emodin. Biochem Pharmacol 94: 39-45.

Guo H, Shen X, Xu Y, et al. 2013a. Emodin prevents hypoxicischemic neuronal injury: involvement of the activin $A$ pathway. NRR 8: 1360-1367.

Guo J, Li W, Shi H, Xie X, et al. 2013b. Synergistic effects of curcumin with emodin against the proliferation and invasion of breast cancer cells through upregulation of miR-34a. $\mathrm{Mol}$ Cell Biochem 382: 103-111.

Ho TY, Wu SL, Chen JC, et al. 2007. Emodin blocks the SARS coronavirus spike protein and angiotensin-converting enzyme 2 interaction. Antivir Res 74: 92-101.

Hsiang CY, Ho TY. 2008. Emodin is a novel alkaline nuclease inhibitor that suppresses herpes simplex virus type 1 yields in cell cultures. Brit J Pharmacol 155: 227-235.

Hwang JK, Noh EM, Moon SJ, et al. 2013. Emodin suppresses inflammatory responses and joint destruction in collageninduced arthritic mice. Rheumatology 52: 1583-1591.

Huang L, Wang XBYOM, et al. 2015. Synergistic cancer growthinhibitory effect of emodin and low-dose cisplatin on gastric cancer cells in vitro. Trop J Pharm Res 14: 1427-1434.

Huang $\mathrm{PH}$, Huang $\mathrm{CY}$, Chen MC, et al. 2013. Emodin and aloeemodin suppress breast cancer cell proliferation through $\mathrm{ER} \alpha$ inhibition. Evid-Based Compl Alt 2013: 376123.

Islam R, Mamat Y, Ismayil I, et al. 2015. Toxicity of anthraquinones: differential effects of rumex seed extracts on rat organ weights and biochemical and haematological parameters. Phytother Res 29: 777-784.

Jelassi B, Anchelin M, Chamouton J, et al. 2013. Anthraquinone emodin inhibits human cancer cell invasiveness by antagonizing P2X7 receptors. Carcinogenesis 34: 1487-1496.

Jia X, Iwanowycz S, Wang J, et al. 2014a. Emodin attenuates systemic and liver inflammation in hyperlipidemic mice administrated with lipopolysaccharides. Exp Biol Med 239: 1025-1035.

Jia X, Yu F, Wang J, et al. 2014b. Emodin suppresses pulmonary metastasis of breast cancer accompanied with decreased macrophage recruitment and $\mathrm{M} 2$ polarization in the lungs. Breast Cancer Res Tr 148: 291-302.

Jin JH, Ngoc TM, Bae K, et al. 2011. Inhibition of experimental atopic dermatitis by rhubarb (rhizomes of Rheum tanguticum) and 5-lipoxygenase inhibition of its major constituent, emodin. Phytother Res 25: 755-759.

Kang DM, Yoon KH, Kim JY, et al. 2014. CT imaging biomarker for evaluation of emodin as a potential drug on LPS-mediated osteoporosis mice. Acad Radiol 21: 457-462.

Kim DY, Kang TB, Shim DW, et al. 2014a. Emodin attenuates A23187-induced mast cell degranulation and tumor necrosis factor- $\alpha$ secretion through protein kinase $C$ and I $\mathrm{KB}$ kinase 2 signaling. Eur J Pharmacol 723: 501-506.

Kim J, Lee JS, Jung J, et al. 2014b. Emodin suppresses maintenance of stemness by augmenting proteosomal degradation of epidermal growth factor receptor/epidermal growth factor receptor variant III in glioma stem cells. Stem Cells Dev 24: 284-295.

Kim JY, Cheon YH, Kwak SC, et al. 2014c. Emodin regulates bone remodeling by inhibiting osteoclastogenesis and stimulating osteoblast formation. J Bone Miner Res 29: 1541-1553.

Kitano A, Saika S, Yamanaka O, et al. 2007. Emodin suppression of ocular surface inflammatory reaction. Invest Ophth Vis Sci 48: 5013-5022.

Lee BH, Huang YY, Duh PD, Wu SC. 2012. Hepatoprotection of emodin and Polygonum multiflorum against $\mathrm{CCl}_{4}$-induced liver injury. Pharm Biol 50: 351-359.

Lee $\mathrm{MH}$, Kao L, Lin C. 2011. Comparison of the antioxidant and transmembrane permeative activities of the different Polygonum cuspidatum extracts in phospholipid-based microemulsions. J Agr Food Chem 59: 9135-9141.

Lee SU, Shin HK, Min YK, Kim SH. 2008. Emodin accelerates osteoblast differentiation through phosphatidylinositol 3-kinase activation and bone morphogenetic protein- 2 gene expression. Int Immunopharmacol 8: 741-747.

Li CL, Ma J, Zheng L, et al. 2012a. Determination of emodin in L02 cells and cell culture media with liquid chromatographymass spectrometry: application to a cellular toxicokinetic study. J Pharmaceut Biomed 71: 71-78.

Li D, Zhang N, Cao Y, et al. 2013a. Emodin ameliorates lipopolysaccharide-induced mastitis in mice by inhibiting activation of NF- $\kappa \mathrm{B}$ and MAPKs signal pathways. Eur J Pharmacol 705: 79-85.

Li M, Fu Q, Li Y, et al. 2014a. Emodin opposes chronic unpredictable mild stress induced depressive-like behavior in mice by upregulating the levels of hippocampal glucocorticoid receptor and brain-derived neurotrophic factor. Fitoterapia 98: $1-10$.

Li WY, Chan RY, Yu PH, Chan SW. 2013b. Emodin induces cytotoxic effect in human breast carcinoma MCF-7 cell through modulating the expression of apoptosis-related genes. Pharm Biol 51: 1175-1181.

Li WY, Ng YF, Zhang H, et al. 2014b. Emodin elicits cytotoxicity in human lung adenocarcinoma A549 cells through inducing apoptosis. Inflammopharmacology 22: 127-134.

Li X, Liu W, Wang Q, et al. 2009. Emodin suppresses cell proliferation and fibronectin expression via p38MAPK pathway in rat mesangial cells cultured under high glucose. Mol Cell Endocrinol 307: 157-162.

Li XX, Dong Y, Wang W, et al. 2012b. Emodin as an effective agent in targeting cancer stem-like side population cells of gallbladder carcinoma. Stem Cells Dev 22: 554-566.

Li Y, Luan Y, Qi X, et al. 2010. Emodin triggers DNA double-strand breaks by stabilizing topoisomerase II-DNA cleavage complexes and by inhibiting ATP hydrolysis of topoisomerase II. Toxicol Sci 118: 435-443.

Lin SP, Chu PM, Tsai SY, et al. 2012. Pharmacokinetics and tissue distribution of resveratrol, emodin and their metabolites after intake of Polygonum cuspidatum in rats. J Ethnopharmacol 144: 671-676.

Liu T, Jin H, Sun QR, et al. 2010. Neuroprotective effects of emodin in rat cortical neurons against $\beta$-amyloid-induced neurotoxicity. Brain Res 1347: 149-160.

Liu W, Feng Q, Li Y, et al. 2012. Coupling of UDPglucuronosyltransferases and multidrug resistanceassociated proteins is responsible for the intestinal disposition and poor bioavailability of emodin. Toxicol Appl Pharmacol 265: 316-324.

Liu X, Liu Y, Qu Y, et al. 2015. Metabolomic profiling of emodininduced cytotoxicity in human liver cells and mechanistic study. Toxicol Res 4: 948-955.

Liu Y, Chen X, Qiu M, et al. 2014. Emodin ameliorates ethanol-induced fatty liver injury in mice. Pharmacology 94: 71-77. 
Liu Y, Jia L, Liu ZC, et al. 2009a. Emodin ameliorates high-glucose induced mesangial p38 over-activation and hypocontractility via activation of PPAR $\gamma$. Exp Mol Med 41: 648-655.

Liu YX, Shen NY, Liu C, Lv Y. 2009b. Immunosuppressive effects of emodin: an in vivo and in vitro study. Transp/ P41: 837-1839.

Liu Z, Wei F, Chen LJ, et al. 2013. In vitro and in vivo studies of the inhibitory effects of emodin isolated from Polygonum cuspidatum on Coxsakievirus B4. Molecules 18: 11842-11858

Lu Y, Yang JH, Li X, et al. 2011. Emodin, a naturally occurring anthraquinone derivative, suppresses IgE-mediated anaphylactic reaction and mast cell activation. Biochem Pharmacol $\mathbf{8 2}$ $1700-1708$

Luo T, Li N, He YQ, et al. 2015. Emodin inhibits human sperm functions by reducing sperm $\left[\mathrm{Ca}^{2+}\right] \mathrm{i}$ and tyrosine phosphorylation. Reprod Toxicol 51: 14-21.

Ma L, Li W. 2014a. Emodin inhibits LOVO colorectal cancer cell proliferation via the regulation of the $\mathrm{Bcl}-2 / \mathrm{Bax}$ ratio and cytochrome c. Exp Ther Med 8: 1225-1228.

Ma J, Yang J, Wang C, et al. 2014b. Emodin augments cisplatin cytotoxicity in platinum-resistant ovarian cancer cells via ROS-dependent MRP1 downregulation. BioMed Res Int 2014: 107671

Ma J, Zheng L, Deng T, et al. 2013. Stilbene glucoside inhibits the glucuronidation of emodin in rats through the down-regulation of UDP-glucuronosyltransferases 1A8: application to a drugdrug interaction study in Radix Polygoni Multiflori. $J$ Ethnopharmacol 147: 335-340.

Manu KA, Shanmugam MK, Ong TH, et al. 2013. Emodin suppresses migration and invasion through the modulation of CXCR4 expression in an orthotopic model of human hepatocellular carcinoma. PLoS One 8: e57015.

Matsuda Y, Yokohira M, Suzuki S, et al. 2008. One-year chronic toxicity study of Aloe arborescens Miller var. natalensis Berger in Wistar Hannover rats. A pilot study. Food Chem Toxicol 46: 733-739.

Naqvi S, Ullah MF, Hadi SM. 2010. DNA degradation by aqueous extract of Aloe vera in the presence of copper ions. Inian $J$ Biochem Bio 47: 161-165.

National Toxicology Program. 2001. Toxicology and carcinogenesis studies of EMODIN (CAS NO. 518-82-1) feed studies in F344/N rats and B6C3F1 mice. National Toxicol Program Tech Rep Ser 493: 1-278.

Ni Q, Sun K, Chen G, Shang D. 2014. In vitro effects of emodin on peritoneal macrophages that express membrane-bound CD14 protein in a rat model of severe acute pancreatitis/systemic inflammatory response syndrome. Mol Med Rep 9: 355-359.

Oshida K, Hirakata M, Maeda A, et al. 2011. Toxicological effect of emodin in mouse testicular gene expression profile. J Appl Toxicol 31: 790-800

Park SJ, Jin ML, An HK, et al. 2015. Emodin induces neurite outgrowth through PI3K/Akt/GSK-3 $\beta$-mediated signaling pathways in Neuro2a cells. Neurosci Lett 588: 101-107.

Peng C, Wang L, Wang YH, et al. 2013. Toxicity mechanism of emodin on interstitial cells of Cajal. Pharmacol Pharm 4: 331-339.

Pooja T, Karunagaran D. 2014. Emodin suppresses Wnt signaling in human colorectal cancer cells SW480 and SW620. Eur J Pharmacol 742: 55-64.

Qian ZJ, Zhang C, Li YX, et al. 2011. Protective effects of emodin and chrysophanol isolated from marine fungus Aspergillus sp. on ethanol-induced toxicity in HepG2/CYP2E1 cells. EvidBased Compl Alt 2011: 45261

Qu K, Shen NY, Xu XS, et al. 2013. Emodin induces human T cell apoptosis in vitro by ROS-mediated endoplasmic reticulum stress and mitochondrial dysfunction. Acta Pharmacol Sin 34: 1217-1228.

Schwarz S, Wang K, Yu W, et al. 2011. Emodin inhibits current through SARS-associated coronavirus 3a protein. Antivir Res 90: 64-69.

Shia CS, Hou YC, Tsai SY, et al. 2010. Differences in pharmacokinetics and ex vivo antioxidant activity following intravenous and oral administrations of emodin to rats. J Pharm Sci 99: 2185-2195.

Shrimali D, Shanmugam MK, Kumar AP, et al. 2013. Targeted abrogation of diverse signal transduction cascades by emodin for the treatment of inflammatory disorders and cancer. Cancer Lett 341: 139-149.

Song P, Kim JH, Ghim J, et al. 2013. Emodin regulates glucose utilization by activating AMP-activated protein kinase. J Biol Chem 288: 5732-5742.
Subramaniam A, Loo SY, Rajendran P, et al. 2013. An anthraquinone derivative, emodin sensitizes hepatocellular carcinoma cells to TRAIL induced apoptosis through the induction of death receptors and downregulation of cell survival proteins. Apoptosis 18: 1175-1187.

Sun Y, Wang X, Zhou Q, et al. 2015a. Inhibitory effect of emodin on migration, invasion and metastasis of human breast cancer MDA-MB-231 cells in vitro and in vivo. Oncol Rep 33: 338-346.

Sun YP, Liu JP. 2015b. Blockade of emodin on amyloid- $\beta$ 25-35induced neurotoxicity in ABPP/PS1 mice and PC12 cells through activation of the class III phosphatidylinositol 3 kinase/beclin-1/B-cell lymphoma 2 pathway. Planta Med 81 . 108-115.

Tong $\mathrm{H}$, Chen $\mathrm{K}$, Chen $\mathrm{H}$, et al. 2011. Emodin prolongs recipient survival time after orthotopic liver transplantation in rats by polarizing the $\mathrm{TH} 1 / \mathrm{TH} 2$ paradigm to $\mathrm{TH} 2$. Anat $R e c 294$ $445-452$.

Wang C, Dai X, Liu $\mathrm{H}$, et al. 2015a. Involvement of PPAR $\gamma$ in emodin-induced HK-2 cell apoptosis. Toxicol In Vitro 29 : 228-233.

Wang C, Wu X, Chen M, et al. 2007a. Emodin induces apoptosis through caspase 3 -dependent pathway in HK-2 cells. Toxicology 231: 120-128.

Wang J, Huang $\mathrm{H}$, Liu $\mathrm{P}$, et al. 2006. Inhibition of phosphorylation of p38 MAPK involved in the protection of nephropathy by emodin in diabetic rats. Eur J Pharmacol 553: 297-303.

Wang JB, Zhao HP, Zhao YL, et al. 2011. Hepatotoxicity or hepatoprotection? Pattern recognition for the paradoxical effect of the Chinese herb Rheumpalmatum $\mathrm{L}$. in treating rat liver injury. PLoS One 6: e24498.

Wang M, Zhao R, Wang W, et al. 2012a. Lipid regulation effects of Polygoni Multiflori Radix, its processed products and its major substances on steatosis human liver cell line L02. J Ethnopharmacol 139: 287-293.

Wang QX, Wu CQ, Liao YM. 2007b. Study on the toxicity and its mechanisms of rhubarb and its major constituents. $J$ Toxicol 21: 310-302.

Wang QX, Wu CQ, Yang HL, et al. 2007c. Cytotoxicity of free anthraquinone from Radix et Rhizoma Rhei to HK-2 Cells. Chinese Journal of New Drugs 16: 189-199.

Wang T, Zhong XG, Li YH, et al. 2015b. Protective effect of emodin against airway inflammation in the ovalbumin-induced mouse model. Chin J Integr Med 21: 431-437.

Wang W, Zhou Q, Liu L, Zou K. 2012b. Anti-allergic activity of emodin on IgE-mediated activation in RBL-2H3 cells. Pharmaco Rep 64: 1216-1222.

Wang YX, Yu H, Zhang YY, et al. 2013. Emodin induces apoptosis of human cervical cancer hela cells via intrinsic mitochondrial and extrinsic death receptor pathway. Cancer Cell Int 13: 71.

Wang YJ, Huang SL, et al. 2012c. Emodin, an 11ß-hydroxysteroid dehydrogenase type 1 inhibitor, regulates adipocyte function in vitro and exerts anti-diabetic effect in ob/ob mice. Acta Pharmacol Sin 33: 1195-1203.

Way TD, Huang JT, Chou $\mathrm{CH}$, et al. 2014. Emodin represses TWIST1-induced epithelial-mesenchymal transition in head and neck squamous cell carcinoma cells through the inhibition of $\beta$-catenin and Akt pathways. Eur J Cancer 50: 366-378.

Wei WT, Lin SZ, Liu DL, Wang ZH. 2013. The distinct mechanisms of the antitumor activity of emodin in different types of cancer (Review). Oncol Rep 30: 2555-2562.

Wesolowska O. 2011. Interaction of phenothiazines, stilbenes and flavonoids with multidrug resistance-associated transporters, P-glycoprotein and MRP1. Acta Biochim Pol 58: $433 \mathrm{e} 48$

Wu L, Cai B, Zheng S, et al. 2013. Effect of emodin on endoplasmic reticulum stress in rats with severe acute pancreatitis. Inflammation 36: 1020-1029.

Wu Z, Chen Q, Ke D, et al. 2014. Emodin protects against diabetic cardiomyopathy by regulating the AKT/GSK-3 $\beta$ signaling pathway in the rat model. Molecules 19: 14782-14793.

Xia XM, Wang FY, Wang ZK, et al. 2010. Emodin enhances alveolar epithelial barrier function in rats with experimental acute pancreatitis. World J Gastroentero 16: 2994-3001.

Xie MJ, Ma YH, Miao L, et al. 2014. Emodin-provoked oxidative stress induces apoptosis in human colon cancer HCT116 cells through a p53-mitochondrial apoptotic pathway. Asian Pac J Cancer $P$ 15: 5201-5205.

Xu JS, Cui Y, Liao XM, et al. 2014. Effect of emodin on the cariogenic properties of Streptococcus mutans and the development of caries in rats. Exp Ther Med 8: 1308-1312. 
Xue J, Chen F, Wang J, et al. 2015. Emodin protects against concanavalin a-induced hepatitis in mice through inhibiting activation of the p38 MAPK-NF-кB signaling pathway. Cell Physiol Biochem 35: 1557-1570.

Xue J, Ding W, Liu Y. 2010. Anti-diabetic effects of emodin involved in the activation of PPAR $\gamma$ on high-fat diet-fed and low dose of streptozotocin-induced diabetic mice. Fitoterapia 81: 173-177.

Yang F, Yuan PW, Hao YQ, Lu ZM. 2014a. Emodin enhances osteogenesis and inhibits adipogenesis. BMC Complem Altern $M$ 14: 74 .

Yang J, Zeng Z, Wu T, et al. 2013. Emodin attenuates high glucose-induced TGF- $\beta 1$ and fibronectin expression in mesangial cells through inhibition of NF-kB pathway. Exp Cell Res 319: 3182-3189.

Yang T, Kong B, Kuang Y, et al. 2015. Emodin plays an interventional role in epileptic rats via multidrug resistance gene 1 (MDR1). Int J Clin and Exp Patho 8: 3418-3425.

Yang Y, Shang W, Zhou L, et al. 2007. Emodin with PPAR $\gamma$ ligandbinding activity promotes adipocyte differentiation and increases glucose uptake in 3T3-LI cells. Biochem Bioph Res Co 353: 225-230.

Yang YC, Lim MY, Lee HS. 2003. Emodin isolated from Cassia obtusifolia (Leguminosae) seed shows larvicidal activity against three mosquito species. J Agr Food Chem 51: 7629-7631.

Yang Z, Zhou E, Wei D, et al. 2014b. Emodin inhibits LPS-induced inflammatory response by activating PPAR- $\gamma$ in mouse mammary epithelial cells. Int Immunopharmacol 21: 354-360.
Yao WY, Zhou YF, Qian AH, et al. 2015. Emodin has a protective effect in cases of severe acute pancreatitis via inhibition of nuclear factor- $\kappa \mathrm{B}$ activation resulting in antioxidation. Mol Med Rep 11: 1416-1420.

Yin X, Gong X, Jiang $R$, et al. 2014. Emodin ameliorated lipopolysaccharide-induced fulminant hepatic failure by blockade of TLR4/MD2 complex expression in D-galactosaminesensitized mice. Int Immunopharmacol 23: 66-72.

Zhang W, Chen H, Liu DL, et al. 2013. Emodin sensitizes the gemcitabine-resistant cell line Bxpc-3/Gem to gemcitabine via downregulation of $\mathrm{NF}-\kappa \mathrm{B}$ and its regulated targets. Int $J$ Oncol 42: 1189-1196.

Zhang W, Li H, Bu H, et al. 2012. Emodin inhibits the differentiation and maturation of dendritic cells and increases the production of regulatory T cells. Int J Mol Med 29: 159-164.

Zhang X, Chen Y, Zhang T, Zhang Y. 2015a. Inhibitory effect of emodin on human hepatoma cell line SMMC-7721 and its mechanism. Afr Health Sci 15: 97-100.

Zhang X, Zhang R, Lv P, et al. 2015b. Emodin up-regulates glucose metabolism, decreases lipolysis, and attenuates inflammation in vitro. J Diabetes 7: 360-368.

Zhou YX, Xia W, Yue W, et al. 2015. Rhein: a review of pharmacological activities. Evid-based Compl Alt 2015: 1-10.

Zhou X, Wang L, Wang M, et al. 2011. Emodin-induced microglial apoptosis is associated with TRB3 induction. Immunopharm Immunot 33: 594-602.

Zhu X, Zeng K, Qiu Y, et al. 2013. Therapeutic effect of emodin on collagen-induced arthritis in mice. Inflammation 36: 1253-1259. 